\title{
THE FORMATION OF AN ELECTRICAL DOUBLE LAYER IN ACID AND NEUTRAL WATER SOLUTIONS ON THE 3-5 $\mathrm{d}^{\mathrm{m}} \mathrm{m}$ METALS
}

\section{A. A. Fedorenko ${ }^{1}$, A. M. Fedorenko ${ }^{1}$, K. D. Pershina ${ }^{2}$}

${ }^{1}$ V. I. Vernadskii Taurida National University, Dzhona Makkeina St., 33, Kyiv 01042, Ukraine ${ }^{2}$ Vernadskii Institute of General and Inorganic Chemistry, Academician Palladin Av., 32/34, Kyiv 03142, Ukraine

e-mail:Pershina@ionc.kiev.ua

The rate-limiting steps of the electrolysis of water solution, taking into account hydrogen evolution overpotential were considered. A functional relationship between the electrical resistivity of 3-5 $\mathrm{d}^{\mathrm{m}}$ metals and their quantization energy of atomic electrons, as well as the coordination of metal atoms and hydrogen compounds, has been revealed. The rule of selecting effective metals for cathodes has been validated. Based on these rules, a reduction-relay mechanism of the hydrogen migration process in the electrical double layer in the electrochemical reduction of $\mathrm{TiO}^{2+}$ ions to $\mathrm{Ti}^{3+}$ and $\mathrm{Fe}^{3+}$ to $\mathrm{Fe}^{2+}$ in sulfuric acid process solutions for the production of pigment titanium dioxide was proposed. The method of the multistage electrochemical reduction of $\mathrm{Fe}^{3+}$ and $\left[\mathrm{TiO}^{2+*} \mathrm{nH}_{2} \mathrm{O}\right]$ in process solutions for the production of titanium dioxide was design based on this study.

Key words: double electric layer, hydrogen evolution, cathode, electron transfer, reduction-relay mechanism.

INRTRODUCNION When improving the sulfate technology for the production of pigment titanium dioxide with the replacement of the chemical reduction of $\mathrm{Fe}^{3+}$ ions to $\mathrm{Fe}^{2+}$ and $\mathrm{Ti}^{4+}$ to $\mathrm{Ti}^{3+}$ with scrap iron and powdered aluminum by the electrochemical method, serious problems arose as to the processes occurring at different cathodes in the electrical double layer (EDL) [1-5]. This especially concerns the electrochemical processes of $\mathrm{Fe}^{3+}$ and $\left[\mathrm{TiO}^{2+*} \mathrm{nH}_{2} \mathrm{O}\right]$ ion reduction in sulfuric acid process solutions with $\mathrm{pH}=2.5-3.0$. In this particular case, the use of the theoretical fundamentals of electrochemistry in prac- tice turned out to be very difficult, especially when using the theory of EDL structure [3]. This primarily concerns the Volmer discharge and Heyrovsky electrochemical desorption stages, which are based on introducing the hydroxonium ion $\left(\mathrm{H}^{+}-\mathrm{OH}_{2}\right)$ into near-cathode electrochemical processes, and based on these concepts, the contradictory slow discharge (SD) theory has been developed. In this theory, it is considered that a significant part of the energy is spent on the rupture of the bond between $\mathrm{H}^{+}$and $\mathrm{H}_{2} \mathrm{O}[4,6-8]$. In the book "Double Layer Theory" [9], published in 2015, no answers as to the use of the EDL theory in applied 
electrochemistry have been unfortunately found. Moreover, neither the recombination theory of hydrogen evolution overpotential $\left(\eta_{\mathrm{H}}\right)$ nor the SD theory is universal. For the metals with high hydrogen adsorption energy, a lower $\eta_{H}$ is observed; therefore, it is recommended to use the recombination theory, and for the metals with lower adsorption, where $\eta_{\mathrm{H}}$ takes on higher values, the $\mathrm{SD}$ theory is recommended, the use of which sometimes gives rise to very contradictory results. There are also questions as to the description of the hydrogen recombination step (Tafel reaction) $2 \mathrm{H}_{\text {ads }} \rightarrow \mathrm{H}_{2}$, i.e. hydrogen molization at the cathode. The complete analysis with using the mathematical analysis of the EDL taking into account the Debye screening length considering heat energy at $298.15^{\circ} \mathrm{K}$, and taking into account the following factors (the role of the hydroxonium ion in the Helmholtz cathode layer, the dependence between of $\eta \mathrm{H}$ and the electrical resistivity of nd m metals, the impact of the complexing ability of nd $m$ metals to hydrogen, impact of the cathode materials and their chemical composition, detection the mechanism of electron transfer from the cathode to the solution the above questions should make it possible to reveal the conditions of the intensification of electrochemical reduction processes of compounds in acid and neutral solutions.

EXPERIMENT AND DISCUSSION OF THE RESULTS. The experimental investigations: measuring and recording instruments: KEL 1M, Shch300.1, Shch1413 conductometers, a digital camera (Kodak Easu Share C 142), a Ts1241 thermostat. Reagents and materials: chemically pure sulfuric acid, bidistilled water, smooth platinum of 99.99 purity, NBR-0 niobium, S-0 lead.

Theoretical and experimental investigations have been carried out to make corrections in the electrolysis theories and concepts of the EDL developed earlier. This primarily concerns the role of the hydroxonium ion and its effect on increase in $\eta_{H^{*}}$ Here, attention should be paid to the dissociation of the complex ion $\mathrm{H}_{3} \mathrm{O}^{+}$:

$$
\left[\mathrm{H}^{+} \cdots \mathrm{OH}_{2}\right] \rightleftarrows \mathrm{H}^{+}+\mathrm{H}_{2} \mathrm{O}
$$

In the eq. (1) the logarithm of the constant $\mathrm{pKa}=-1.7011$; it follows that the equilibrium is shifted to the right, and that it displays the properties of a medium acid, which decomposes spontaneously into ions. Besides, the research carried out by Conway, Borkis and Linton (1956) to determine the stability of $\mathrm{H}_{3} \mathrm{O}^{+}$, which was, in terms of time, $0.024 \times 10^{-12} \mathrm{~s}$, should be taken into consideration [6]. Subsequent research to determine the lifetime of $\mathrm{H}_{3} \mathrm{O}^{+}$was carried out by the scientist Meiboom in 1961 by the NMR method at $298.15^{\circ} \mathrm{K}$, which was $1.7 \times 10^{-12} \mathrm{~s}$. In the opinion of the above scientists, such a low stability of the species $\mathrm{H}_{3} \mathrm{O}^{+}$does not allow it to move independently in water (the mobility of $\mathrm{H}_{2} \mathrm{O}$ is $\left.3.62 \times 10^{-3} \mathrm{~cm}^{2} \mathrm{~V}^{-1} \mathrm{~s}^{-1}\right)$ as a structural unit, and the very high mobility of $\mathrm{H}^{+}$is due solely to proton exchange. In this particular case, in the presence of polarization of water molecules, the proton is transferred along a chain of hydrogen bonds by the Grotthuss relay mechanism. The presence of the independent species $\mathrm{H}_{3} \mathrm{O}^{+}$in water is also ruled out because of the formation of hydrogen bonds of neighboring molecules to it $[10,12]$, i.e. the formation of $\left[\mathrm{H}^{+} \ldots\left(\mathrm{OH}_{2}\right)_{\mathrm{n}}\right]$, where $\mathrm{n} \geq 2$. When a potential is applied in electrolysis, the $\mathrm{H}^{+}$ions will be the first to reach the cathode surface because at the equal positive charges of $\mathrm{H}^{+}$and $\mathrm{H}_{3} \mathrm{O}^{+}$, the positive charge of the latter species will be smaller because of its loss by electrostatic interaction between water and proton dipoles. Besides, the mass of $\mathrm{H}^{+} \approx 1 \mu \mathrm{u}$ 
should be taken into account, and the mass of $\mathrm{H}_{3} \mathrm{O}^{+}$is 19 times larger. It follows that $\mathrm{H}_{3} \mathrm{O}^{+}$is a more inert species. Research has been carried out to determine the functional dependence of hydrogen evolution overpotential $\left(\eta_{H}\right)$ on the electrical resistivity of $\mathrm{nd}^{\mathrm{m}}$ metals [13]. Based on electron energy quantization and the theory of the chemistry of coordination compounds $[13,14]$, a well-defined functional dependence of $\eta_{\mathrm{H}}$ for $3 \mathrm{~d}^{\mathrm{m}}, 4 \mathrm{~d}^{\mathrm{m}}$ and $5 \mathrm{~d}^{\mathrm{m}}$ transition metals on the electron occupancy of $\mathrm{d}^{\mathrm{m}}$ orbitals is revealed. This dependence for $3 \mathrm{~d}^{\mathrm{m}}$ elements is shown in Figs 1 and 2.

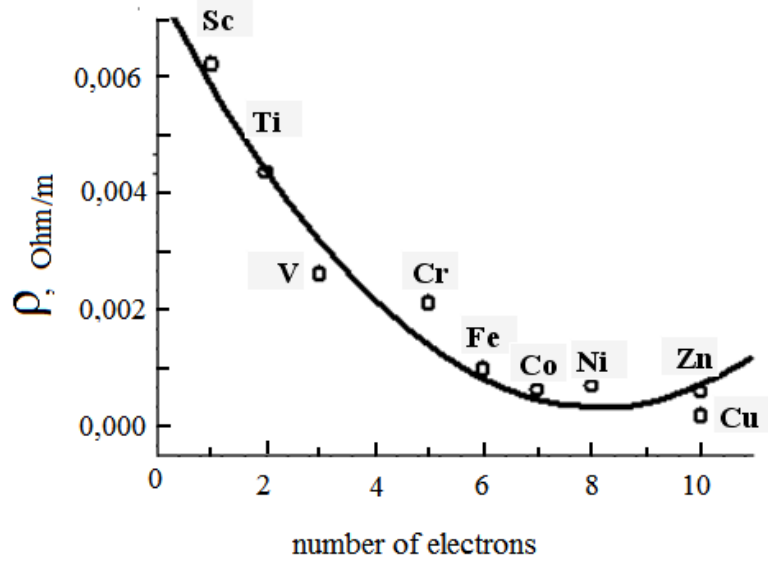

Fig 1. Dependence of electrical resistivity $(\rho)$ on the electron occupancy of $3 \mathrm{~d}^{\mathrm{m}}$ orbitals.

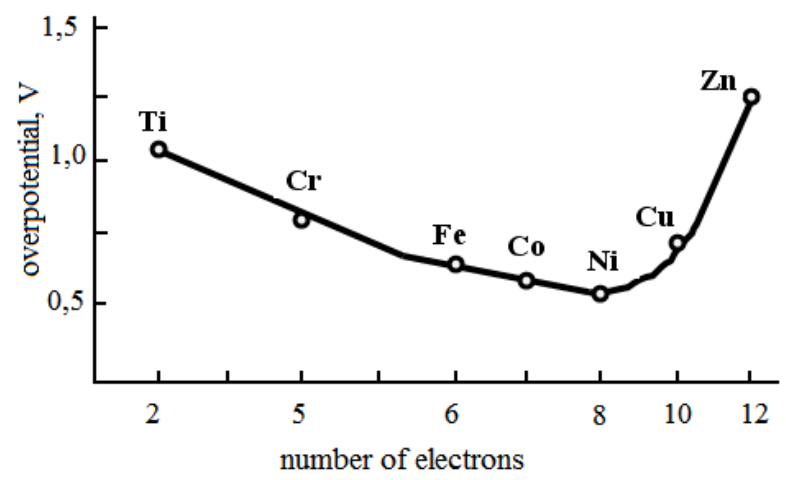

Fig 2. Dependence of hydrogen evolution overpotential on the electron occupancy of $3 \mathrm{~d}^{\mathrm{m}} 4 \mathrm{~s}^{\mathrm{n}}$ orbitals.
When comparing the plots in Figs 1 and 2, within filling the orbitals with 1 to 10 electrons, an analogous (symbatic) behavior of the curves is observed, which corroborates this dependence. For the p electrons of large-period atoms, an antibatic behavior of the curves is observed; therefore, it is recommended to use the electronegativity $(\mathrm{EN})$ of elements relative to $\mathrm{EN}_{\mathrm{H}}=2.1$. A decrease in $\eta_{\mathrm{H}}$ is observed only if $\mathrm{EN}_{\mathrm{H}}<2.1$.

For the $\mathrm{d}$ elements, the theory of the chemistry of coordination compounds should be taken into account, on the basis of which it becomes possible to explain the causes of the decrease in $\eta_{\mathrm{H}}$. First of all, the $\mathrm{nd}^{\mathrm{m}}$ metals must be divided into two groups: I, metals with filled orbitals, where $\mathrm{m}=1-8$ electrons; II, metals with $\mathrm{nd}^{\mathrm{m}}$ sublevels filled with up to 10 electrons. Group I includes metals with specific adsorption (chemisorption), which is characterized by a high hydrogen adsorption energy (solid solutions) and manifests itself by a decrease in $\eta_{H}$ in electrolysis, and group II includes metals with low hydrogen adsorption energy, which results from electrostatic forces. Therefore, these metals possess a higher $\eta_{\mathrm{H}}$ value. The manifestation of specific adsorption is observed in the case of the presence of unoccupied orbitals or unpaired electrons on the orbitals of $\mathrm{nd}^{\mathrm{m}}$ metals. This results in the formation of shared pairs between the metal and hydrogen compounds according to the scheme:

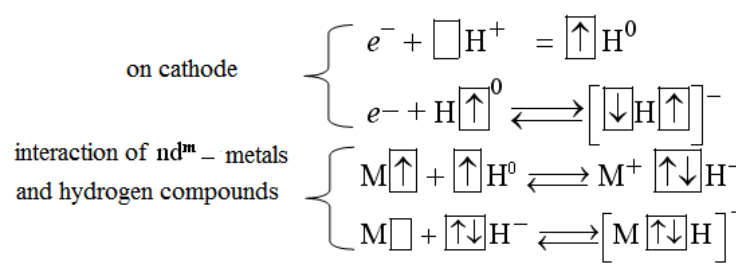


The products of reactions (1) and (2) appear because of the formation of an electric field intensity by an electron, which reaches tens of millions of volts per centimeter at a distance of $1.0 \mathrm{~nm}$. This results in the appearance of atomic hydrogen, followed by its deformation polarization and the formation of a hydride ion.

The cause of decrease in $\eta_{H}$ of group I metals is explained by the theory of coordination compounds. Consider this decrease for the ${ }^{55.849} \mathrm{Fe}$ metal as an example:

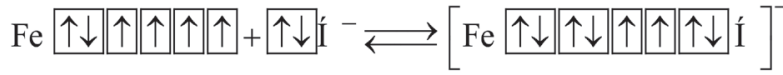

As a result of interaction between $\mathrm{Fe}$ and $\mathrm{H}^{-}$, in view of (3) and (4), the electronic configuration of the iron atom, $3 \mathrm{~d}^{6}\left(\right.$ term $\left.{ }^{5} \mathrm{D}_{4}\right)$, changes into $3 \mathrm{~d}^{8}\left(\right.$ term $\left.^{3} \mathrm{~F}_{4}\right)$; thus, Fe takes on the configuration of nickel, which has minimum $\rho$ values (Fig 1) and the same $\eta_{\mathrm{H}}$ value (Fig 2). It is proposed to consider, as an example, a brass alloy $(\omega, \%: \mathrm{Cu}, 60 ; \mathrm{Zn}, 40)$ : electronic configuration of atoms (ECA) $\left(\mathrm{Cu}, 3 \mathrm{~d}^{10} 4 \mathrm{~s}^{1} ; \mathrm{Zn}, 3 \mathrm{~d}^{10} 4 \mathrm{~s}^{2}\right)$; $\rho_{\text {brass }}{ }^{*} 10^{6 *} \Omega^{*} \mathrm{~cm}=6.81$; the activity of metals for coordination to hydrogen is low (group II). Example with polymetallic steel $(12 \mathrm{Kh} 18 \mathrm{~N} 10 \mathrm{~T})$ : $\operatorname{ECA}\left(\mathrm{Cr}, 3 \mathrm{~d}^{5} 4 \mathrm{~s}^{1} ; \mathrm{Ni}, 3 \mathrm{~d}^{8} 4 \mathrm{~s}^{2}\right) ; \rho_{\text {steel }}{ }^{*} 10^{6 *} \Omega^{*} \mathrm{~cm}=$ 70-75; they interact actively with hydrogen (I). From the above information it follows that $\rho_{\text {brass }}$ is 10 times lower than $\rho$ of $12 \mathrm{Kh} 18 \mathrm{~N} 10 \mathrm{~T}$. However, when determining $\eta_{\mathrm{H}}$, the Tafel constant for brass at $50{ }^{\circ} \mathrm{C} \mathrm{a}=-1.02$, the exchange current $\mathrm{j}_{0}=6.8 \times 10^{-9} \mathrm{~A} / \mathrm{cm}^{2}$, and for $12 \mathrm{Kh} 18 \mathrm{~N} 10 \mathrm{~T}, \mathrm{a}=0.87, \mathrm{j}_{0}=6.5 \times 10^{-8} \mathrm{~A} / \mathrm{cm}^{2}$; therefore, it is better to use steels containing $\mathrm{nd}^{\mathrm{m}}$ metals with $\mathrm{m}<10$ and $\mathrm{Pd}$ with double dip of electrons.

Thus, the chief thing is that the formation of a $\mathrm{H}^{-}$coordination bond to the metals $\mathrm{Fe}$, $\mathrm{Cr}, \mathrm{Ni}$ contained in the cathode surface took place, which affected greatly the electron transfer from the cathode to the EDL saturated with unreduced hydrogen compounds. The following compounds are meant in the first place: $\mathrm{H}^{+}, \mathrm{H}_{2}{ }^{+}\left(\mathrm{D}_{\mathrm{c}}=2.80 \mathrm{eV}\right), \mathrm{H}_{3}{ }^{+}\left(\mathrm{D}_{\mathrm{c}}=\right.$ $3.04 \mathrm{eV}), \mathrm{H}_{4}{ }^{+}\left(\mathrm{D}_{c}=1.10 \mathrm{eV}\right)$, where $\mathrm{D}_{c}$ is the dissociation energy. The reason of the variety of the compounds of $\mathrm{H}^{0}$ is its relatively high electronegativity $\left(\mathrm{EN}_{\mathrm{H})}=2.10\right.$; for comparison, $\mathrm{EN}_{(\mathrm{F})}=3.98$ ), which provides filling its inert gas $(\mathrm{He})$ type electron shell. Among 100 elements of the periodic table with established $\mathrm{EN}, \mathrm{EN}_{(\mathrm{H})}$ predominates in 77 of them; most of them reveal the formation of various hydride compounds.

When there is a potential at the cathode in the presence of electrostatic and specific adsorption, the following processes can occur simultaneously in the Helmholtz layer: $\left[\mathrm{e}^{-}\right]_{\mathrm{c}}{ }^{*} \mathrm{H}^{+}=\mathrm{H}^{0}$; (2) $\mathrm{H}^{0}+\mathrm{H}^{+} \rightarrow \mathrm{H}_{2}^{+}$; (3) $\left[\mathrm{e}^{-}\right]_{\mathrm{c}}{ }^{*} \mathrm{H}^{0} \rightarrow \mathrm{H}^{-}$; (4) $\mathrm{H}^{-}+\mathrm{H}^{+} \rightarrow \mathrm{H}_{2} ;(5) \mathrm{H}^{0}+\mathrm{H}^{0} \rightarrow \mathrm{H}_{2} ;(6) \mathrm{H}_{2}+\mathrm{H}^{+} \rightarrow \mathrm{H}_{3}^{+}$; (7) $\mathrm{H}_{3}{ }^{+} \rightarrow \mathrm{H}_{2}{ }^{+}+\mathrm{H}^{0}$; (8) $\mathrm{H}_{4}^{+} \rightarrow \mathrm{H}_{3}^{+}+\mathrm{H}^{0}$; (9) $\mathrm{H}^{-}+$ $\mathrm{H}^{0} \rightarrow \mathrm{H}_{2}^{-}$, where $\left[\mathrm{e}^{-}\right]_{\mathrm{c}}$ is the cathode. The series of hydrogen transformations has been made up on the basis of an extensive review of publications and experimental data. The presence of species directly at the cathode surface with the manifestation of pronounced specific adsorption in electrochemical processes is determining in $\eta_{\mathrm{H}}$ decrease and the reduction of $\mathrm{Fe}^{3+}$, $\left[\mathrm{TiO}^{2+*} \mathrm{nH}_{2} \mathrm{O}\right]$.

The hydrogen species $\mathrm{H}^{-}, \mathrm{H}_{2}^{-}, \mathrm{H}^{0}, \mathrm{H}^{+}, \mathrm{H}_{2}^{+}$ are involved to a greater extent in these processes; this manifests itself especially when the electron is transferred from the cathode via the hydride ion along a reduction-relay chain by means of a molecular hydrogen ion $\left(\mathrm{H}_{\mathrm{a}}^{0}-\mathrm{H}_{\mathrm{b}}{ }^{+}\right)$. In view of quantum mechanics, the transfer of a single electron in the molecular ion $\left(\mathrm{H}_{\mathrm{a}}{ }^{0}-\mathrm{H}_{\mathrm{b}}{ }^{+}\right)$occurs owing to electron oscil- 
lation between two nuclei. This state is more fully described by the resonance integral $\mathrm{H}_{\mathrm{ab}}=\mathrm{H}_{\mathrm{ba}}=\int \phi_{\mathrm{a}} \mathrm{H} \phi_{\mathrm{b}} \mathrm{d} \tau=\int \phi_{\mathrm{b}} \mathrm{H} \phi_{\mathrm{a}} \mathrm{d} \tau$, which is a ground for creating a theory of the reduction-relay mechanism of $\mathrm{H}^{+}$reduction and electron transfer to the acceptor. To confirm these judgments, the systems $\mathrm{H}_{2} \mathrm{SO}_{4}-\mathrm{H}_{2} \mathrm{O}\left(\mathrm{I}^{*}\right)$ and $\mathrm{H}_{2} \mathrm{SO}_{4}-\mathrm{TiOSO}_{4}-\mathrm{H}_{2} \mathrm{O}\left(\mathrm{II}^{*}\right)$ with the same $\mathrm{pH}=0.87$ (Fig 3) have been investigated. $\mathrm{Nb}$ metal $[14,15]$ and $12 \mathrm{Kh} 18 \mathrm{~N} 10 \mathrm{~T}$ steel were used as the cathodes, and a $12 \mathrm{Kh} 18 \mathrm{~N} 10 \mathrm{~T}$ mesh coated with a $\mathrm{MnO}_{2 \text { (therm) }}$ multilayer coating was used as the anodes (Fig 3).

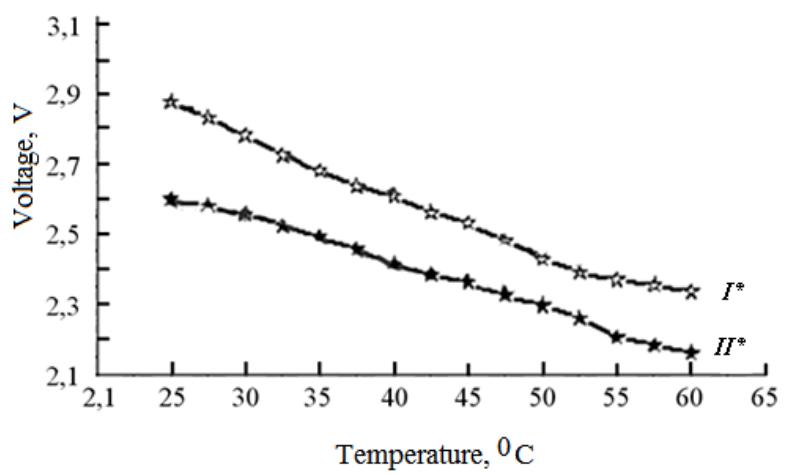

Fig 3. Dependence of voltage on the solution temperature in the systems:

$(12 \mathrm{Kh} 18 \mathrm{~N} 10 \mathrm{~T})_{(\mathrm{c})}-\left(\mathrm{MnO}_{2}\right)_{(\mathrm{a})}-\mathrm{H}_{2} \mathrm{SO}_{4}-\mathrm{H}_{2} \mathrm{O}$

$(12 \mathrm{Kh} 18 \mathrm{~N} 10 \mathrm{~T})_{(\mathrm{c})}-\left(\mathrm{MnO}_{2}\right)_{(\mathrm{a})}-\mathrm{TiOSO}_{4}-\mathrm{H}_{2} \mathrm{SO}_{4}-\mathrm{H}_{2} \mathrm{O}$

As a result of investigating the systems $\mathrm{I}^{*}$ and $\mathrm{II}^{*}$ (Fig 3), a functional dependence of voltage on temperature $\left(25-60^{\circ} \mathrm{C}\right)$ has been established; a noticeable decrease in voltage in the systems is clearly visible. In the system II $^{\star}$, however, this decrease is more noticeable because of electron transfer by the reduction-relay mechanism via the ions $\mathrm{H}^{-}, \mathrm{H}_{2}{ }^{+}$, etc, to the acceptor cation $\left[\mathrm{TiO}^{2+*} \mathrm{nH}_{2} \mathrm{O}\right]$. In the electrolysis in the system $\mathrm{I}^{*}$, the rate-limiting step of the $\mathrm{H}^{+}$reduction process is the molization $\mathrm{H}^{0}+\mathrm{H}^{0}=\mathrm{H}_{2}$, which is hindered by the presence in the Helmholtz layer of molecular species $\mathrm{H}_{2}{ }^{+}, \mathrm{H}_{3}{ }^{+}$, etc, which affect the cathode potential. However, this state is favorable for electron transfer to the acceptor.

The process of electrochemical reduction of $\left[\mathrm{TiO}^{2+\star} \mathrm{nH}_{2} \mathrm{O}\right]$ in the Gouy layer is confirmed by a thermal effect, measured directly on the $\mathrm{Nb}$ cathode. During hydrogen reduction in the systems $\mathrm{I}^{\star}-\mathrm{Nb}$ and $\mathrm{II}^{\star}-\mathrm{Nb}$, the sensors recorded small heat energy changes of $\Delta \mathrm{t}=0.188^{\circ} \mathrm{C}\left(\mathrm{I}^{*}-\mathrm{Nb}\right)$ and $0.334^{\circ} \mathrm{C}\left(\mathrm{II}^{*}-\mathrm{Nb}\right)$, which is unexpected since during hydrogen recombination and molization, an energy of $18.1 \mathrm{eV}$ is released. In view of this, a calculation taking into account the change $\Delta t$, the heat capacity of the niobium cathode $(15 \mu \mathrm{m}$ foil), the heat capacity and heat conductivity of adsorbed hydrogen on the cathode and a determination of the size of the fixed Helmholtz layer have been performed. When processing the experimental data on hydrogen reduction in the system $\mathrm{I}^{*}-\mathrm{Nb}$, it turned out that the experimental heat energy $\left(\mathrm{Q}_{\exp }\right)$ was $9.5 \times 10^{16} \mathrm{eV}$, and the theoretical heat energy $\left(\mathrm{Q}_{\text {theor }}\right)$ with allowance for release at the cathode must be $5.4 \times 10^{21} \mathrm{eV}$, i.e. $5.6 \times 10^{4}$ times as high. Thus, the ion reduction process occurs outside the cathode, i.e. at some distance from it. To determine the size of the Helmholtz layer, quantum-mechanical calculations have been made to establish the dependence of the Debye screening length of electrode potential on the concentration of solutions (Fig 4). The number of hydrogen species on the cathode surface has been determined taking into account the heat energy of $0.013 \mathrm{eV}$ at $298.15^{\circ} \mathrm{K}$. 


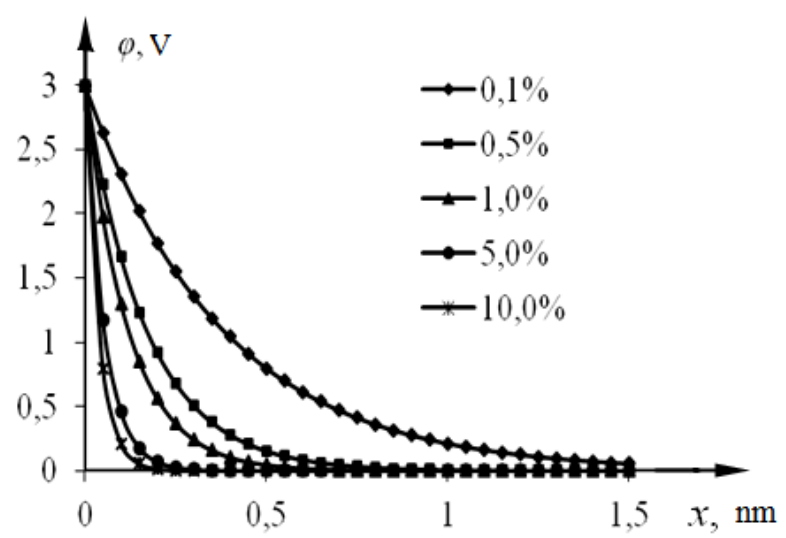

Fig 4. Electric potential distribution in the cathode region for $\mathrm{H}^{+}$ion concentration values $(\omega, \%=$ $0.1-10)$ in sulfuric acid solutions at $298.15^{\circ} \mathrm{K}$.

In view of Fig 4 , the electrochemical reduction of $\mathrm{Fe}^{3+}$ and $\left[\mathrm{TiO}^{2+*} \mathrm{nH}_{2} \mathrm{O}\right]$ in process solutions for the production of titanium dioxide should be performed in the presence of 5.0-10.0\% sulfuric acid in multistage electrolyzers (Fig 5), for at these concentrations, the thinnest fixed Helmholtz layer with a thickness of 2-3 hydrogen species is formed. The basic diagram of a multistage electrolyzer is shown in Fig 5.

This electrolyzer provides an accelerated electron transfer from the cathode to the electron acceptors, with the reduction energy $\left(Q_{\exp }\right)$ increasing to $1.6 \times 10^{17} \mathrm{eV}$ (system $\left.\mathrm{B}^{\star}-\mathrm{Nb}\right)$. Hence the electrochemical reduction process is carried out with maximum values of convective diffusion in the Gouy layer. The group I nd ${ }^{\mathrm{m}}$ metals must be used for the cathode materials, but still more effective results are achieved when using their alloys because besides the existence of specific adsorption, the property of the hydrogen evolution synergism manifests itself.

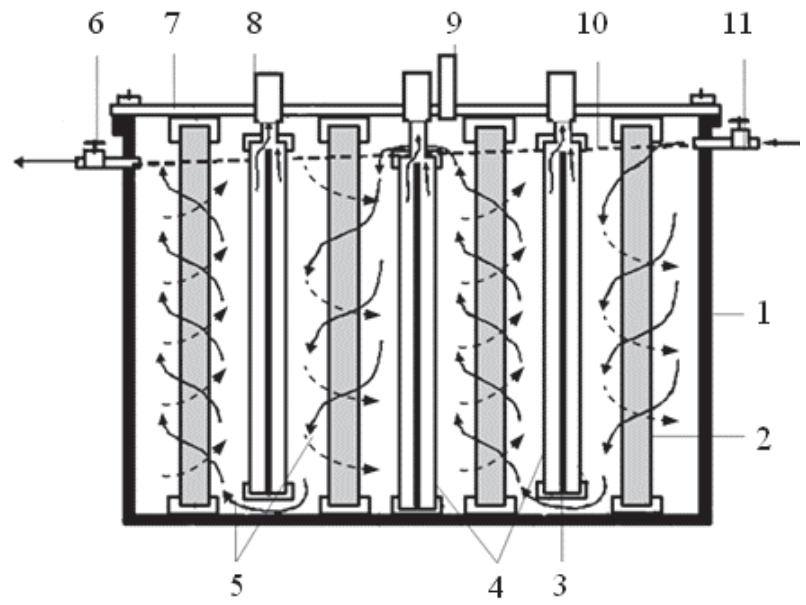

Fig 5. Basic diagram of a multistage electrolyzer: (1) electrolyzer body, (2) mesh cathode, (3) anode, (4) membrane, (5) direction of electrolyte movement, (6) electrolyte drain cock, (7) electrolyzer cover, $(8,9)$ gas outlet tube of the anode and cathode, (10) electrolyte level, (11) cock.

\section{Conclusions}

A method for identifying promising metals and their alloys for cathodes based on the electrical resistivity of $\mathrm{nd}^{\mathrm{m}}$ metals and the theory of the chemistry of coordination compounds has been proposed. The factors affecting the hydrogen evolution overpotential in the EDL have been determined based on quantum-mechanical calculations. A model of the reduction-relay mechanism of electron transfer from the cathode to the Helmholtz EDL, followed by electron migration into the Gouy slip layer and to the electron acceptors $\left(\mathrm{Fe}^{3+},\left[\mathrm{TiO}^{2+\star} \mathrm{nH}_{2} \mathrm{O}\right], \mathrm{H}^{+}\right.$, etc $)$, has been proposed. Thermal effects on the cathode have been studied, which support the mechanism of electron transfer under hydrogen reduction and the reduction of ions in the Helmholtz layer $\left(\mathrm{H}^{+}\right)$and in the Gouy layer $\left(\mathrm{H}^{+}\right.$, 
$\left.\left[\mathrm{TiO}^{2+*} \mathrm{nH}_{2} \mathrm{O}\right]\right), \mathrm{Fe}^{3+}$, etc. The method of the multistage electrochemical reduction of $\mathrm{Fe} 3+$ and $\left[\mathrm{TiO}^{2+*} \mathrm{nH}_{2} \mathrm{O}\right]$ in process solutions for the production of titanium dioxide was designed based on this study.

The work was done under financial support of the Ministry of Education and Science of Ukraine according themes: «Development of basics of solution chemistry, improvement of chemical-technological processes, study of structure, physicochemical properties and methods of analysis of natural sorbents, biopolymers, glycosides, food, winemaking and food impurities» (DR № 0106U003194); "Improvement of chemical-technological processes; study of physicochemical properties of coordination compounds, natural zeolites, bentonites, plant enzymes, glycosides, polysaccharides and obtaining nanocomposite materials based on them «(DR № 0111 U000644).
УТВОРЕННЯ ПОДВЙНОГО ЕЛЕКТРИЧНОГО

ШАРУ В КИСЛИХ ТА НЕЙТРАЛЬНИХ ВОДНИХ РОЗЧИНАХ НА 3-5 d'M-MЕТАЛАХ

Федоренко А. А. ${ }^{1}$, Першина К. Д. ${ }^{2}$, Федоренко А. M. ${ }^{1}$

${ }^{1}$ Таврійський національний університет ім. В. I. Вернадського, вул. Джона Маккейна, 33, Київ 01042, Україна

${ }^{2}$ Інститут загальної та неорганічної хімї ім. В. I. Вернадського, просп. Акад. Палладіна 32/34, Київ 03142, Украйна

e-mail:Pershina@ionc.kiev.ua

Розглянуто стадії електролізу розчинів у водних розчинниках, що впливають на обмеження швидкості електрохімічної реакції з урахуванням потенціалу перенапруги виділення водню. Виявлено функціональний взаємозв'язок між електричним опором металів 3-5 дм та енергією квантування їхніх атомних електронів, а також координацією атомів металів та сполук водню. Встановлено правило вибору ефективних металів для катодів. Виходячи 3 цього правила, було запропоновано реле-редукційний механізм процесу міграції водню в подвійному електричному шарі при електрохімічному відновленні іонів $\mathrm{TiO}_{2}^{+}$до $\mathrm{Ti}^{3+}$ i $\mathrm{Fe}^{3+}$ до $\mathrm{Fe}^{2+}$ у технологічних розчинах сірчаної кислоти для отримання пігменту діоксиду титану. На основі цього дослідження було розроблено метод багатоступеневого електрохімічного відновлення $\mathrm{Fe}^{3+} \mathrm{i}\left[\mathrm{TiO}_{2}{ }^{+*} \mathrm{nH}_{2} \mathrm{O}\right]$ у технологічних розчинах для отримання діоксиду титану.

Ключові слова: подвійний електричний шар, виділення водню, 3-5 $\mathrm{d}^{\mathrm{m}}$-метали, катод, перенесення електрону, редукційно-естафетний механізм. 


\section{REFERENCES}

1. Skomoroha V.M., Zarechnyj V.G., Vorob'eva I.P., Vakal S.V. Proizvodstvo dvuokisi titana sul'fatnym sposobom. Sumy: ATZT «Arsenal press». 2002. 204 p. (In Russian).

2. Antropov L.I. Teoreticheskaya elektrohimiya. K.: Lybid'. 1993.544 p. (In Russian)

3. Fedorenko A.M., Fedorenko A.A. . Quantum theory of electronic conductivity of substances and problems of electrochemistry. Simferopol': IP Baranovskiy A.E. RF Respublika Krym. 2019. 200 p. (In Russian)

4. Fetter K. Electrochemical kinetics. M.: Khimiya. 1967. 856 p. (In Germany)

5. Pershina, E.D., Karpushin, N.A. \& Kazdobin, K.A. Aluminosilicate conductivity at the presence of water. Surf. Engin. Appl. Electrochem. 2010. 46: 339-347. https://doi.org/10.3103/S1068375510040083

6. Bockris J. O'M. and Reddy A. K. N.. Modern Electrochemistry 1:Ionics. Plenum Press, New York. 1998.

7. Henderson, D., \& Boda, D. Insights from theory and simulation on the electrical double layer. Physical Chemistry Chemical Physics. 2009. 11(20): 3822-3830.

DOI: $10.1039 / \mathrm{b} 815946 \mathrm{~g}$

8. Skorchelletti V.V. Theoretical electrochemistry. Leningrad: Khimiya. 1974. (In Russian)
9. Salem R.R. Double layer theory. Moscow: Fizmatlit. 2015. (In Russian)

10. Zatsepina G.N. Properties and structure of water. Moscow: Moscow State University Press. 1974. (In Russian)

11. Pershina, E.D., Kazdobin, K.A. Conductivity of water media as an alternative of electronic and ionic transfer. J. Water Chem. Technol. 2008. 30: 358-367. https://doi.org/10.3103/S1063455X0806 0052

12. Pershina, E.D., Kokhanenko, V.V., Maslyuk, L.N. et al. Conductivity of aqueous suspensions of alumosilicates. Surf. Engin. Appl.Electrochem. 2011. 47: 441-445. https://doi.org/10.3103/S1068375511050176

13. Kotton F., Uilkinson Dzh. Sovremennaya neorganicheskaya himiya chast'. 1. M.: Mir. 1969. 224 p. (In Russian)

14. Henrici-Olive G., Olive S. Coordination and catalysis. Moscow: Mir. 1980. (In Russian)

15. Bairachnyi B.I., Fedorenko A.A., Tulskii G.G. et al. Resursosberegayushchie elektrohimicheskie processy $\mathrm{v}$ proizvodstve pigmentnogo dioksida titana. Zhurnal prikladnoj himii. 2013. 86(7): 1069-1073. (In Russian)

Стаття надійшла 14.02.2020. 